\title{
Sciendo
}

DOI: $10.2478 /$ rjp-2019-0010

Rom J Psychoanal 2019, 12(1):195-206

Rom J Psychoanal

\section{CĂRTĂRESCU FROM THE DISTANCE AND BEYOND THE SEAS}

Guillermo Julio Montero PhD 20

«Though I can't remember it, I could never forget it.»

Solenoid (p. 154)

\section{Foreword}

If I were prompted to choose one of the core subjects of Solenoid - among a lot of possible interesting ones - I would not hesitate to select the subject of reality. Let's listen to the author:

«What is reality? Which is the visceral and metaphysical drive that transforms what is objective in subjective?» (p. 526).

What Cărtărescu names «visceral and metaphysical drive» leads to fear, and this is the reason why he also writes:

«I can't help thinking that reality is just fear in itself, iced fear. I live with fear, I breathe fear, I swallow fear, I will be buried in fear. I pass my fear from one generation to the next, in the same way I received it from my parents and grandparents» (p. 399).

But reality brings not only fear but also strangeness:

${ }^{20}$ The International Psychoanalytical Association; guillermontero@hotmail.com 
«How strange is the world in which I live! It doesn't seem real, but rather a stage built for me that disappears the moment I lose its perception. How many times would I have wished to turn my back suddenly just to capture by surprise the hectic work of scene-shifters, the colliding of decoration, the fall of the buildings constructed with a single wall tied from behind, or, simply, the dissolution of all sensory stimuli in a kind of emptiness equivalent to death!» (p. 624).

The core of the novel is also a heart-breaking story in search of authenticity: how does each individual need to «invent» reality to acknowledge he/she is born. The author makes an effort to understand what individuals name as reality - something that from the very beginning everybody achieves in isolation.

Solenoid hopes to become a complete novel. It encompasses the entire life of its main character, dressed in the clothes of the author. I want to pay attention to what I am stating: Cărtărescu doesn't hide himself in the main character, but the main character disguises himself as Cărtărescu - something completely different - a literary mechanism that only a genius such as Cărtărescu may accomplish.

But Solenoid is also a descent into hell and a way back to the world: a kind of alchemical transmutation ending with an open door to the uncertainty of being, and with a closing chapter open to hope.

This is the reason why it's easy to confuse the novel with an autobiographic device or with a memoir: false data. As the main character disguises himself as Cărtărescu, the narrator has a kind of freedom that is absent from autobiographies and memoirs.

The story mutates from (invisible) peculiarities of the body internal organs, the deep composition of organic matter - towards the (invisible) peculiarities of the Universe, the subtle laws that rule the 
different dimensions, specifically the fourth dimension, trying to update an essential human search for what is meant as the microcosmmacrocosm equation, just to suggest that the «phenomena of life and death»- listen up- would remain unknown.

We can find several other symbols or emblems in the novel - all of them working as a meaningful nucleus: the history of the «anomalies» - as he names them - of the main character, Bucharest as a primal myth, dioramas as an attempt to replace reality with a precision mechanism, solenoid as an energetic field making several phenomena out of the human scope possible, Hinton's squares and the tesseract as a mechanism able to render visible the fourth dimension, the mirror as a reflection within the mystery of duplicity: the archaic dread that one day the mirror won't reflect our image but nothing in itself, the «picketists»' sect as representatives of humankind in horror, dread and fighting against death, photographs as representations of unbearable absence and the camera lucida as the instrument making it possible, mites (acari) as the evidence of another complex kind of life that dwells within us, Nicolae Vaschide and his dream-sculpting workshop, working with whores who tried to reach the orama: the supreme dream, the Voynich manuscript as the archetype of that which will never be deciphered but certainly hides an important truth; plaster gorgons, satyrs and bacchantes hanging from Bucharest's balconies, Nicolae Minovici's controlled hanging techniques, attempts at experiencing what happens at the moment of death, stereograms with the optical illusion of the third dimension, Dylan Thomas' poem Do Not Go Gentle into that Good Night, the antikhytera Greek mechanism used to predict astronomical positions and eclipses, pheromones as a magic against aphanisis, the number 7129 always 
returning - such as the 2719 times the author repeats the expression Help! (pp. 687-97): the same numbers as 7129 etc.

But among the novel's emblems I want to highlight what I named «the prisoner's metaphor» - repeated and hinted at many times - because I believe it an important articulator, full of meaning, all along the story. (pp. 70, 87, 92, 95, 97, 125, 265, 299, 300, 361, 432, 437, 438, 522, 533, 534, 536, 553, 592, 601, 659, 672, 707, 711, 722, 723, 732, 735, 740, 765,782 [for sure there are many others I think I didn't consider]).

\section{«The Prisoner's Metaphor»}

This is the story of a prisoner that was rotting his life away in prison for many years. Sentenced to life imprisonment, he is so carefully watched that he is sure his life will end in the dungeon. But one night he listens to some slight knocks on one of the walls. He brings his ear closer and can listen to these knocks with much more clarity: bright, intelligent, an elaborated series of knocks that are repeated at regular intervals. For the sake of clarity, the prisoner believes in one of the hallucinations that used to serve as his company in prison. But the following day and at the same hour, he listens again to the series of knocks on the wall, and so, again and again, one day after the other. He decides to memorise the series of sounds, and begins to write them on the part of the wall hidden by the bed. Every now and then, these alternations become more complicated, as if the neighbour on the other side of the wall were introducing new «words» into the code. The prisoner needs several months to intuit the first connections in the secret warp of the knocks and to find meaning in its language afterwards. Finally, the prisoner begins to answer to the series trying to use the same code (written by himself in an invented spelling with half-moons, gearwheels, crosses and triangles scrawled in the plaster) and begins to give shape to a kind of a dialogue. The neighbour - he now understands - is explaining to him an escape plan of such audacity that takes his breath away, and, at the same time, of an incredible simplicity. One night, after having carried out all the necessary preparations, following the instructions verbatim, the prisoner 
manages to escape. After several years, rich and famous, living under a false identity, he asks for permission to visit the prison with the goal of finally meeting the person he owed everything, and in hopes of being able to rescue him as well. He is led to the cell where he wasted his youth away and, once there, he asks the guardian for the-other-side-of-thewall's prisoner. But, to his surprise, he is told that on the other side there are only the sky and the sea. The wall, dozens of meters above where waves break on the stone shore, faces the exterior directly. Mircea Cărtărescu, Solenoid (p. 70).

The shocking power of Cărtărescu's tale may be synthesized in the following series of elements:

1. The prisoner invents an object he relates to.

2. The prisoner invents a language.

3. The prisoner escapes from prison.

4. The ex-prisoner returns to free his cell neighbour.

The selected paragraph implies a full compendium of psychoanalysis, because it underlines how the internal world shapes reality, because the prisoner received knocks and sounds, and he could have otherwise devised a really different thing from his escape. It seems as if he had hope and this made him find the proper decoding method to express this internal hope. The decoding each individual does is always much more important than the specific external factor that causes it.

The need to build an inner object is a need to find a way out (tohave-a-life). We could think that, when the object is absent, we need to find an event in order to build it, because the threat is dissolution.

The prisoner was in the need of «inventing» an other to think, because he just listened to the messages as someone else's messages. When he «understood» we as having a place in the mind of another individual who was willing to help him, he «invented» that other one instead of the hallucinations to which he was accustomed to. 
Of course, this leads to the question of whether it is possible to find an object - as is the case of the prisoner - if it wasn't settled/ established before, even in a precarious way, or if there wasn't at least a trace of that experience.

Both premises lead to a kind of tension that is very important to hold: an other individual is needed as an existent one in order to find a way out, because if that other individual doesn't exist we need to create it through the mechanism of invention.

It's a paradox, but the prisoner could have also found a paranoid resolution of his situation, because the text states that «he is watched so carefully» (p. 70), that we could easily think that he could have «chosen» it to obtain a dissolution of his personality... and here is where internal psychic resources and psychic working -through are needed.

Of course, I can't leave without stressing that prison is also the absence of an object.

Thinking in Winnicottian terms, we could also consider the prisoner as someone who had the ability to solve the riddle of the knocks he heard because he could incorporate the capacity to be alone (in the presence of another individual). I consider that the inference of the presence of another individual manifested as the knocks on the wall that lead the prisoner to that certainty. In the same way, the sea may also represent the maternal primal object speaking those sounds that the prisoner can decode. I think so, because the sea has always been there and because we must be sure that the knocks have been there from the very beginning of his imprisonment, but they become noticeable to the prisoner at a specific moment, and from then on he began to decode the knocks and noises. 
From Piera Aulagnier's perspective, the sounds the prisoner decodes are pictographic representations, something equivalent to the sounds that the mother's body produces and that reach the embryo during pregnancy: intrauterine life.

The prisoner escapes «following the instructions verbatim», says the author in a beautiful sentence, because the verbatim instructions were an invention of the prisoner himself, that is to say his plan for a new life was something he had planned himself.

When he understands that the other individual in the neighbouring cell is not there, because there is no such a cell or such an other, the prisoner, now a free man acknowledges that he had developed a full language for his own freedom. In other words, his freedom was and is within him.

«You can't escape until you believe you are able to escape, even though you were in a cell with strong, thick walls, without doors and windows» (p. 265).

In some way, the psychoanalyst's work may be compared to the work of the prisoner: decoding the sounds, the music, the rhythms, the cadence that build the language of the unconscious that the psychoanalyst (the prisoner) has to articulate and try to understand.

The prisoner's metaphor also alludes to the human condition, because all of us are in life imprisonment: death is waiting for us at the end of the road and there's no alternative way out. Life imprisonment implies imprisonment until death: human beings are alive up to the exact moment when they die. The prisoner is fundamentally trying to escape the human death-sentence... and he realises this (in the same way that that other bright Cărtărescu characters: our beloved roulette player, who 
can always survive the game of the roulette because he's a literary character.)

«We grow old, we wait quietly on death row. We are executed one after the other in the most sinister extermination camp. We are first stripped of beauty, youth and hope. We are wrapped in the penitent's cloth of disease, tiredness and decay» (p. 181).

The paragraph alludes to an audacity that seems related to the essential dare to have-a-life, let's say: to be alive till death arrives (as it is said Winnicott once told his wife).

We can also identify a developmental understanding of the prisoner's metaphor, because the references to age and the passing of time make it clear that the prisoner is a man in his middle age, who spent his youth in prison.

I think that midlife allows us to work-through the understanding of the life imprisonment to which we are condemned, and everyone may be the prisoner of Cărtărescu's story, if we decode those incoming messages that urge us towards freedom.

As I already told you, it is really important to highlight in what specific moment the prisoner began to listen to the sounds coming from «the outer side», because these had surely been there forever: they were the noises of nature! And this is why I consider that what happens to the prisoner is equivalent to what happens during midlife, because the «noises» coming in are related to drive increase, and the true possibility of listening to them is what allows the subjective renewal we can find during maturescent working-through (Montero, 2019).

I say that midlife demands urgency for the deciphering of a new code, finding an escape plan, something that may be re-signified: 
Which are these new words?

What is the new code?

We could also wonder why the prisoner comes back:

Why couldn't the prisoner think that «both» had escaped?

Why did he assume that his cell neighbour remained in prison?

This return may initially be understood as an evidence of the psychic working-through activity showing any kind of (symbolic) regression. We could also think that the object the prisoner built was an equivalent of the primary object, and that he regains contact with it due to an inner need. Moreover, we could think of him coming back with a feeling of gratitude. In some way, the prisoner «comes back» as an expression of the typical working-through activity of psychic secondary processing. Following Piera Aulagnier's concepts, we could think that secondary process gives meaning to what he lived pictographically.

Why does he return with a false identity?

Which is his real identity?

Is escape from «life imprisonment» only possible through a false identity?

Now, we could also think of a rare paradox: prison under an authentic identity and freedom under a false identity! (What a strange paradox!)

We can also take into consideration two antithetic possibilities to understand why the prisoner returns. First, he went back to acknowledge his true agent of transformation, that which allowed him to live free. Second, we could think he went back because he still acknowledges parts of his self are imprisoned, and goes to their rescue. 
As I've already stated, the paragraph also expresses a metaphor for human existence: all of us are the prisoner, all of us live listening to different noises, such as the words of other individuals, the effects other individuals have on us, everything we can imagine coming from outside is «rebuilt» within the limits of our subjectivity. What's there «in the other side»? We will never know because we are all in the same prison of our existence, where we came alone and from which we will depart alone as well, and we could never know how we enter this world and how we leave it. An enriching and encouraging metaphor!

Psychoanalytically speaking, the noises coming from the other side of the wall can be likened to sexual excitement when listening to the noises of the parental couple having sex, something that also demands a decoding activity of the mind, promoting psychic development.

Of course, it is not hard to draw a line between Plato's cavern allegory and Cărtărescu's prisoner metaphor.

In the novel we can also find allusions to the mystery of the anatomical differences between the sexes and sexual reproduction (Freud, 1925j):

«However, intercourse and death depicted another story, one we weren't allowed to understand at that moment, but that reached our ears through hundreds of illegal and dark roads» (p. 458).

«They lose their status as gods when they have intercourse, and grow old after, they wrinkle, they bend their backs, they lose their teeth, they lose their hair, they get horrible illnesses, and finally they die. They don't tell us the truth about birth and death because they don't want us to see how they are in reality: passing shadows in this world» (p. 459). 
Growing old is an important theme all throughout the novel, and Cărtărescu puts it in the words of several characters, not only in the main protagonist, where we can also find the shadow of the fear of aphanisis (Jones, 1927).

From this vertex, we find a perspective from inside the hell of existence and another from the external world:

\section{A perspective from inside the hell of existence:}

«They now knew that vulva lips were dry, and that the penis, half in erection, and that April, May and June had already passed as in a dream, without any possibility of coming back. Men, bald and white haired, would have offered anything to feel again, yes, even that hard pain in the testicles when they returned home, after ten bus stops, by night, having spent dead hours on the lonely bench in the square with the girl who, now, a mature woman, is moving with difficulty in his arms, sweaty and hot as they will never be again in this life that is inexorably degrading» (p. 177).

2. A perspective from the external world (a key to escape from prison!):

«Yes, we could see the line of the future, formed by thousands and thousands of individual lines dancing along the centre of everybody and of no one. What has been will happen again, we say. The sun will rise tomorrow because it has risen since we are aware of ourselves, and our ancestors testified that in their time it also rose daily. Men were born, lived, had children, and died. Life lasted seventy years old, for the strongest about eighty years old. This will always remain the same for as 
long as planet Earth lasts. All of us foresee this future interwoven with millions of examples. Reinforced by millions of phantasmal lines. It is as if we had behind our eyes a bridge over a river, but just because yesterday it was there, and in the past, and several decades ago. So we can walk over the river with the certainty of having firm ground under our feet» (p. 729).

This opens the hope that the end of the novel lets the reader follow the main character with his wife and daughter going to live in the country, full of love and wisdom after a dark night, in a renewed way.

But... there is always a «but»... perhaps we could already infer what crime the prisoner committed, the reason of his imprisonment. I hope the reader can now think of something that would allow him/her to understand what is the crime about which I am speaking.

\section{REFERENCES}

CĂRTĂRESCU, M. (2017). Solenoide. Impedimenta, Barcelona.

FREUD, S. (1925j). Some Psychical Consequences of the Anatomical

Distinction between the Sexes, SE XIX.. Hogarth Press, London, pp. 459-472. JONES, E. (1927). The Early Development of Female Sexuality. Int $J$ Psychoanal 88: 459-472.

MONTERO, G.J. (2019). Psychoanalysis of Maturescence: The Onset of Midlife and Beyond. First International Conference on Psychoanalytic Perspectives on Aging, San Diego, California, p. 10. 